\title{
EFFECT OF PARAMPHISTOMUM CERCARIAE ON THE HEART RATE OF GYRAULUS LAEVIS (ALDER)
}

\author{
Erian G. Kamel ${ }^{1}$
}

Ayşe Burgu²

Gyraulus laevis (Alder)'in kalp atışları üzerine Paramphistomum serkerlerinin etkisi

Özet: Mayıs 1986'da Eskişehir Çifteler Harasından toplanan tatlısu sümüklüsü Gyraulus laevis'lerin binoküler disseksiyon mikroskobunda Paramphistomum gelişme dönemleri yönünden kontrolü yaptlmıstır. Parazitli bulunanlar deklorinize çeşme suyu içeren petri kutularında, kuvvetli ışık altında 2 saat tutularak serker çıkarmaları sağlanmışır.

Bu çalışmada 51 parazitli (Paramphistomum serkeri çıkaran), 76 parazitsiz sümüklü kullanılmıs olup, ayrı petrilere $\left(25^{\circ} \mathrm{C}\right.$ de ve deklorinize suda) yerleştirilen her sümüklünün en az 60 dakika kalp atışlart saytlmıştır. Parazitsiz olan sümüklülerin kalp atıslar toplanmalarından 3 hafta sonra sayılmis, ayrıca içlerinde sporokist, redi gibi gelişme dönemleri bulumup bulunmadı̆̆ daha sonra disseke edilerek araştırılmıştır.

Parazitli ve parazitsiz sümüklüler kabuk çaplarına göre $A, B, C$ olarak (0.3-0.39,0.4-0.49,0.5-0.6 mm) üc farklı gruba ayrtmuştrr. Parazitli sümüklü gruplarmda ortalama kalp atış sırasıyla $84.22 \pm 5.68$, $76.16 \pm 14.53$ ve $69.40 \pm 10.27$ atıs sayısı/dakika iken, parazitsiz gruplarda $62.19 \pm 9.62,47.46 \pm 7.79$ ve $42.08 \pm 5.41$ atıs saytst / dakika bulunmuştur. Enfekte sümüklülerin kalp atışlarının belirgin şekilde artmus olduğu gözlenmiş ve artıs yüzdeleri sirasıly 35.42, 60.47 ve 64.92 olarak saptanmiştır.

Paramphistomum serkerleri ile enfekte Gyraulus laevis'in kalp atışlarındaki bu artışın nedeni tam olarak açıklık kazanmamıştır. Digenetik trematod larvalar ile enfekte sümüklülerde kesin olarak belirlenen bu durumun açıklı̆̆a kavuş̧urulması için biyokimyasal çalışmalara gerek vardir.

1 Associate Professor, Ain Shams University, Women College For Arts, Science and Education, Cairo, Egypt.

2 Doç.Dr. A.Ü. Veteriner Fakültesi, Parazitoloji Anabilim Dalı, Ankara, Türkiye. 
Summary: The heart rate of the fresh water snail Gyraulus laevis significantly increased as a result of parasite infection with Paramphistomum cercariae.

The percentage increase in the heart rate (beats / minute) of parasitized snails was $35.42,60.47$ and 64.92 (in water, $T-25^{\circ} \mathrm{C}$ ) in three different size groups $A, B$ and $C(0.3-0.39 \mathrm{~mm} 0.4-0.49 \mathrm{~mm}$ and $0.5-0.6 \mathrm{~mm}$ in shell diameter).

A definite explanation for the increase in the heart rate of parasitized Gyraulus laevis with Paramphistomum cercariae is far from being certain. Biochemical studies are necessary to elucidate the precise cause of the greater heart rate in parasilized snails with digenetic trematode larvae.

\section{Introduction}

Many species of gastropod molluscs suffer parasitic infection by asexual stages of digenean trematodes, some of great medical importance. There is an increasing literature about the metabolic interrelationships between the parasite and the molluscan host (1).

The life history of digenetic trematodes is complicated by successive larval form known as parthenite which may multiply abundantly within the molluscan host. The degree of complexity of the life history of the parasite varies with species and may involve one or two intermediate host which harbour the larval forms.

In parasitized snaiis with digen $\epsilon$ tic larval trematodes, one can expect to find pathological manifestation induced by the trematode larvae. Such alternation from the normal can be appreciated as physiological and histopathological changes.

Little information is available on the influence of digenetic larval trematodes on the physiological changes of gastropod hosts, despite the general reviews by $(3,11,16)$. Cheng (4) suggests that the effects of parasitism on the general physiological state of the snail host include: increased shell growth of the host, pigmentacion, thinning and ballooning of shells, rise in body temperature and desrruction $\mathrm{cf}$ circulation, increased calcium content in the tissue, decrease in haemolymph protein and glucose concentrations, increased heart rate and oxygen uptake. 
The heart rate is probably the commonest parameter in comparative physiology, in a given animal is one of the most variable characteristics (12). In general, the heart rate is faster in small animals of a given kind than in larger ones. Also heart rate varies greatly with exercise, rest or locomotor activity, it is lower in sluggish animals than in related active ones. Schwartzkopff (13) considered Helix pomatia together with several other terrestrial species as active pulmonates hawing a heart rate of 40-70 beats / minute, whilst Lymnaea stagnalis and other fresh water pulmonates are comparatively inactive with a heart rate of 15-40 beats/minute.

Little observation is available on the effect of parasitism on the heart rate of the snail host. Apparently the only work investigating the effect of parasitic infection on the heart rate of gastropod molluscs is that of Lee and Cheng (10) on the snail Biomphalaria glabrata infected with Schistosoma mansoni; Kamel (8) on Littorina littorea parasitized with Cryptocotyle lingua; Kamel et al (9) on the fresh water snail Lanistes carinatus Olivier parasitized with xiphidiocercariae.

In Turkey, the district of Eskişehir Chifteler State Farm, is one of the areas where fresh water snails are widespread. According to a recent investigation carried out by Burgu (2) seven different types of fresh water snails were collected from this area. The most common was Planorbis planorbis, the snail intermediate host of Paramphistomum cervi in Turkey.

The present study is the first of a series deals with host-parasite relations of Paramphistomum cercariae and the fresh water snail Gyraulus laevis which harbour Paramphistomum cercariae. This investigation was carried out to observe and compare the heart rate of unparasitized Gyraulus laevis and those parasitized with Paramphistomum cercariae.

\section{Materiais and Methods}

Gyraulus laevis used in the present investigation were collected on May 28, 1986 from Eskişehir Çifteler State Farm 250 kilometer west of Ankara, Turkey. Snails were transported to the laboratory where they were maintained in plastic aquaria half filled with dechlorinated tap water. Snails were liberally supplied with fresh lettuce leaves until used in the experiment. 
Parasitized Gyraulus laevis with Paramphistomum cercariae can be identified and separated from unparasitized ones by detecting the different developing stages of the parasite such as sporocysts, rediae and cercariae through the transparent shell using binocular dissecting microscope. Parasitized specimens were kept individually in small perri dishes for about two hours exposed to light, to allow mature cercariae to emerge. Snails shedding cercariae were only used for measuring the heart beats of parasitized specimens.

Heart beats of unparasitized snails were measured after three weeks of collecting the specimens. Snails were examined after counting heart beats in order to find non-emerged cercariac and their parthenite (rediae or sporocysts) by crushing the snails and examined under dissecting microscope to ensure that they are free from infection.

Fifty one specimens of Gyraulus laevis parasitized with Paramphistomum cercariae and seventy-six unparasitized ones were used in this investigation. The heart rate of each snail was ascertained by direct observation and counting under dissection microscope. Each snail was submerged in a small bowl containing dechlorinated tap water and the heart rate was recorded as beats per minute. The heart rate of each specimen was observed and measured for at least 60 minutes. After determining the heart rate of each snail, its shell diameter was subsequently determined. Snails were classified according to their shell diameter into three size groups. Group A $(0.3-0.39 \mathrm{~mm})$ group B $(0.4-0.49 \mathrm{~mm})$ and group $C(0.5-0.6 \mathrm{~mm})$.

Observations were made on the behaviour of each snail during recording of the heart rate. This allowed the heart rate associated with the activity (active rate) and quiescent (standard rate) to be calculated independently. Regression lines were fitted to the maximum and minimum heart rate.

\section{Results}

A total of $1226(0.30-0.6 \mathrm{~mm}$ in shell diameter $)$ specimens of Gyraulus laevis collected from Eskişehir Çifteler State Farm, west of Ankara, Turkey, were examined for digenetic larval trematode infections. Fifty-three specimens were parasitized with Paramphistomum cercariae $(4.32 \%)$. All infections involved one species only. There was no case of infection with two species of digenea. Most infection were moderate to heavy. 
The results obtained from measuring the heart rate in water (temperature $=25^{\circ} \mathrm{C}$ ) of quiscent unparasitized and parasitized Gyraulus laevis are summarized in Table 1 . It is clear from the data presented that the difference between the mean heart rate (beats / minute) of quiescent parasitized and unparasitized Gyraulus laevis in three different size groups is statistically significant.

The mean heart rate in three parasitized groups $A, B$ anc $C$ was 84.22 -1: $5.68,76.16 \pm 14.53$ and $69.40 \pm 10.27$ beats/minute compared with $62.19 \pm 9.62,47.46 \pm 7.79$ and $42.08 \pm 5.41$ beass/ minute recorded for unparasitized groups $\mathrm{A}, \mathrm{B}$ and $\mathrm{C}$ respectively. The overall mean heart rate of 45 quiscent parasitized specimens $(76.59 \pm$ 10.16 beats / minute and 70 quiescent unparasitized ones $(50.57 \pm$ 7.60 beats / minute) is statistically significant $(P<0.001)$. The results indicated the significantly greater heart rates of parasitized snails. The percentage increase in the heart rate of three parasitized grouns (A,B and C) was $35.42,60.47$ and 64.92 respectively. The overall percentage increase of parasitized specimens was $51.45 \%$.

The active heart rate of parasitized and unparasitized Gyraulus laevis submerged in water is summarized in Table 2 . The results show that the active heart rate of both parasitized and unparasitized snails are greater than that recorded for quiescent ones. Unparasitized specimens showed a mean heart rate of $72.39 \pm 4.92$ beats / minute compared with a mean heart rate of $93.33 \pm 2.86$ beats / minute recorded for parasitized snails with Paramphistomum cercariae. The percentage increase in the heart rate of active parasitized snails was $28.92 \%$.

Figure 1 presents the relationship between the heart rate (beats/ minute) and the shell diameter ( $\mathrm{mm}$ ) of both quiescent unparasitized and parasitized Gyraulus laevis. It is evident from the graph that the heart rates of both snails parasitized and unparasitized with Paramphistomum cercariae decrease as the shell diameter increases.

\section{Discussion and Conclusion}

A number of obvious inter-related factors, such as environmental conditions and the behaviour of the intermediate and final hosts, may be expected to account for the incidence of infection in Gyraulus laevis parasitized with Paramphistomum cercariae. The percentage of infected Gyraulus laevis with Paramphistomum cercariae was $4.32 \%$ 
Table 1. Quiescent heart rates of uninfected Gyrmulus laevis and those infected with Paramphistomum cercariae.

\begin{tabular}{|c|c|c|c|c|c|c|c|}
\hline \multirow[b]{2}{*}{$\begin{array}{l}\text { Size groups } \\
\quad(\mathrm{mm})\end{array}$} & \multicolumn{3}{|c|}{ Uninfected snails } & \multicolumn{3}{|c|}{ Infected snails } & \multirow[b]{2}{*}{$\begin{array}{l}\text { T-test applied } \\
\text { to means }\end{array}$} \\
\hline & $\begin{array}{c}\text { Number } \\
\text { of snails } \\
(70)\end{array}$ & $\begin{array}{l}\text { Mean heart } \\
\text { rate } \pm \text { S.D. } \\
\text { (beats / min) }\end{array}$ & Range & $\begin{array}{c}\text { Number } \\
\text { of snails } \\
(45)\end{array}$ & $\begin{array}{l}\text { Mean heart } \\
\text { rate } \pm \text { S.D. } \\
\text { (beats } / \mathrm{min} \text { ) }\end{array}$ & Range & \\
\hline $\begin{array}{ll}\text { A) } & 0.30-0.39 \\
\text { B) } & 0.40-0.49 \\
\text { C) } 0.50=0.60 \\
\end{array}$ & $\begin{array}{r}(9) \\
(40) \\
(21) \\
\end{array}$ & $\begin{array}{l}62.19 \div 9.62 \\
47.46 \pm 7.79 \\
42.08 \pm 5.41 \\
\end{array}$ & $\begin{array}{l}54-78 \\
38-69 \\
36-51 \\
\end{array}$ & $\begin{array}{r}(5) \\
(19) \\
(21) \\
\end{array}$ & $\begin{array}{lr}84.22 & 5.68 \\
76.16 \pm & 14.53 \\
69.40 \pm & 10.27\end{array}$ & $\begin{array}{l}76-91 \\
62-86 \\
54-77 \\
\end{array}$ & $\begin{array}{l}P<0.01 \\
P<0.001 \\
P<0.001\end{array}$ \\
\hline $\begin{array}{l}\text { overall heart } \\
\text { rate } \pm \text { S.D. }\end{array}$ & & $50.57 \div 7.60$ & & & $76.59 \pm 10.16$ & & \\
\hline
\end{tabular}




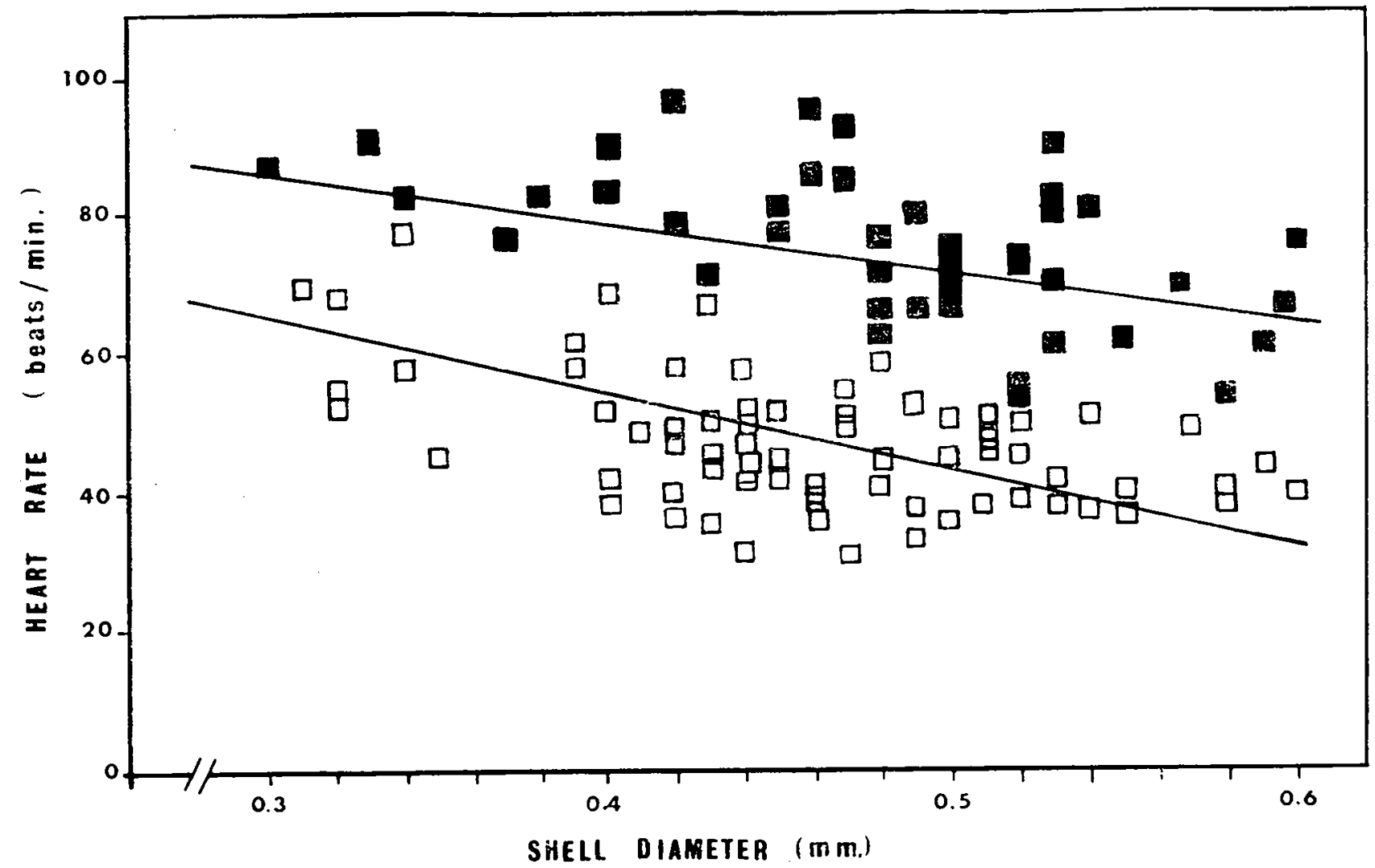

Fig.1. Heart rate in relation to shell diameter of uninfected $\square$ and infected Gyraulus laevis. Regression lines are fitted to the maximum and minimum heart rates. 
Table 2. Active heart rate of uninfected Gyrululus laevis and those infected with Paramphistonum cercariae.

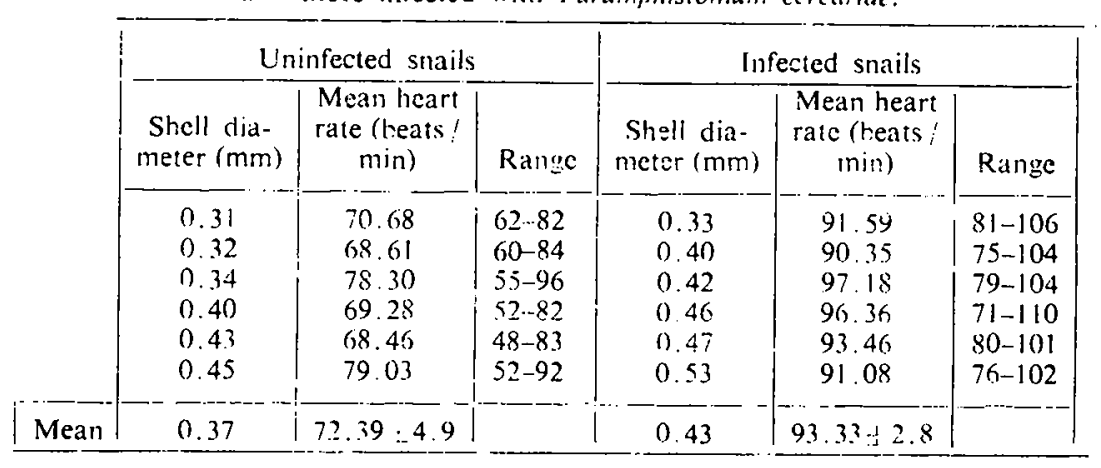

(0.3-0.6 $\mathrm{mm}$ in shell diameter) at Eskişchir Çifteler State Farm, Turkey, during May, 1986.

Counting the heart rate by dircet observation under binocular dissection microscope seems to be well used specially in snails with transparent shells as Gyraulus laevis $(6,10,14,15)$.

Little information is available on the effect of larval trematode on the heart rate of the snail host. In the present investigation an experiment was carried out to observe and compare the heart rate of both unparasitized and parasitized Gyraulus laevis.

The present investigation indicated that parasitized Gyraulus laevis with Paramphistomum cercariae have a significantly higher heart beats per minute than those unparasitized snails. The mean heart rate (beats / minute) for three different size groups ranging from 0.30 to $0.60 \mathrm{~mm}$ in shell diameter was $84.22+5.68,76.16 \pm 14.53$ and $69.40 \div 10.27$ beats / minute compared with $62.19+9.62,47.46 \pm$ 7.79 and $42.08+5.41$ beats/minute recorded for unparasitized snails. The mean heart rate of 45 parasitized specimens was 76.59 土 10.16 compared with $50.57 \pm 7.60$ as a mean of 70 unparasitized specimens is statistically significant $(P<0.001)$. The overall percentage increase in the heart rate of parasitized snails was $51.45 \%$ for quiescent specimens and $28.92 \%$ for active ones.

The only similar results available are those of Lee and Cheng (10) which showed an increase in the heart rate of Biomphalaria glabrata parasitized with Schistosoma mansoni by $43.58 \%$ (at $24^{\circ} \mathrm{C}$ ) and $29.89 \%$ (at $26^{\circ} \mathrm{C}$ ). Kamel (8) on Littorina littorea parasitized with 
Cryptocotyle lingua measured the heart rate by four different techniques recorded an overall increase of heart rate in parasitized anima's as $34.13 \%$. Lanistes carinatus parasitized with xiphidiocercariae showed an increase of $32.32 \%$ in the heart rate compared with unparasitized snails (9).

Cheng and Bier (5) indicated that the time at which the heart rate of parasitized Biomphalaria glabrata commences to be significantly different from that of uninfected snails, corresponds to the period when the enclosed daughter sporocysts of Schistosoma mansoni begin producing cercariae. In the present study similar phenomenon occured in Gyraulus laevis parasitized with Paramphistomum cercariae since the parasitized snails used in measuring the heart rate were shedding cercariae.

The possible explanation for the increase in the heart rate of parasitized Gyraulus laevis with Paramphistomum cercariae is that the parasite within the molluscan host either directly or indirectly, through stimulation of the nervous system, cause cardio-excitation (tachycardia) or reduce the cardio-inhibitor. On the other hand the parasite could produce, as a metabolic by product, some form of substance which increases the heart beats. Jones and Kamel (7) indicated a reduction in blood volume of parasitized L. littorea with $C$. lingua. This reduction in blood volume will lead to a more rapid circulation of the blood to ensure adequate supply to the tissue. It is possible that a similar phenomenon occurs in the present study.

Comprehensive biochemical studies are necessary to elucidate the precise cause of the greater hcart rate in Gyraulus laevis parasitized witl Paramphistomum cercariae.

\section{References}

1. Becker, W. (1980). Metabolic interelationship of parasitic trematodes and molluscs, especially Sthistosoma mansoni in Biomphalaria glabrata. Z. Parasitenkd., 63, 101111.

2. Burgu, A. (1982). Studies on the biology of Paramphistomum cervi Schrank. 1709 in sheep in the district of Eskişehir Cifteler State Farm. A.Ü. Vet. Fak. Derg., 28, (1-4), $50-71$.

3. Cheng, T.C. (1967). Marine molluscs as host for symbioses: with a review of known parasites of commercially important species. Adv. Mar. Biol., 5, 1-424. 
4. Cheng, T.C. (1973). "General Parrsitology". Academic Press. Now York.

5. Cheng, T.C. and Bier, J.W. (1972). Studies on molluscan Schistosomiasis: An analysis of the development of the cercaria of Schistosoma mansoni. Parasitology, 64, 129-14n.

6. Harrison, P.T.C. (1977). Seasunal changes in the heart rate of the fresh water pulmonate L.ymnaeu stagnalis (L.) Comp. Biochem. Physiol. 58A. 37-41.

7. Jones, H.1). and Kamel. E.G. (1984). The etfect of Cuptoconlls lingua infection on the blood velume of Littorina littored. Comp. Biochsm. Physiol., 79 А, 493-494.

8. Kamel, F.G. (1979). The physiological effects of plat helmintin ;ratasites on littorina littorea (L.). Ph. D. Thesis, Manchester Lniwrsit?. Zoolragy Rept. En:land.

9. Kamel. E.G., Abrle! Reheem, L., Mohamed, A.M. and Hanna, M.Y. (1986). Aitteration

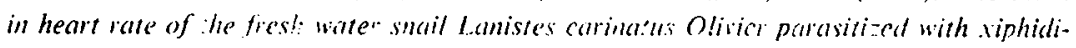
ocercariue. Proc. Er.: p:. Acad. Sci, (in preis).

10. Lee, F.O. and Cheng, T.C. (1971). Schistosoma mansoni infertion in Biomphalaria glabrata: Alteration in heart rate and thermal toiercince in the host. J. Invertebr. Pathol., 18. 412-41:

11. Malek, E.A. and Cheng, T.C. (1974). "Medical and Economical Malacol'sy". Academic Press. New York, London.

12. Prosser, C.L. (1973). "Comparative Animal Physiolugy". W. B. Saunders, Philadelphia.

13. Schwartzkopff, J. (1957). Herzfrequenz und Körpergrosse bei Mollısken. Zool. Ang., Suppl. 20, 46.3-469.

14. Tsukuda, H. and Ohsawa, W. (1959). Temperature dependence and acclimatizaton of the rate of heart of a red snail Phy'sa sp. in relation to size. J. Inst. Polvtechs. Osaka rity Univ., 10, 105-113.

15. Von Brand, T. and Mehlman, B- (1953). Relationship between pre-and post-anacrobic oxygen consumption and oxygen tension in some fresh water snails. Biol. Bull., 104, $301-312$.

16. Wright, C.A. (1966). The pathogenesis of helminth in mollusca. Helminth. Abstr., 35 (3), $207-224$. 